\title{
Elite education and problems of forming professional elites
}

\author{
Pavel Karabushchenko ${ }^{1 *}$, Farida Rekesheva $^{1}$, and Leonid Podvoisky ${ }^{1}$ \\ ${ }^{1}$ Astrakhan State University, Department of Political Science, Astrakhan, Russia
}

\begin{abstract}
The real world is experiencing serious transformational changes associated with the crisis of the globalist (monopolar and multicultural) project and the growth of post-industrial trends. Under these conditions, the role of many professional elite communities is also changing, as well as the emphasis of their assessments and roles in the global social process. Since elites are in every field of professional activity, it is needed to study the phenomenon of the elite from the viewpoint of the community of certain selected groups responsible for forming a response to the challenge of their era. The goal of the present work is to show the role of elite (open and highquality) university education in the formation of professional qualities of contemporary elite communities. The authors used various methods ranged from dialectics and hermeneutics to comparative studies and semiotics. This set of research methods allowed penetrating the depth of the qualitative parameters of elite communities, as well as giving them a comprehensive assessment. In this regard, a special role is given to the principles of personalism, which reveal the depth of the elite personality and the meaning of their creative process. It is this task, i.e. uncovering the meaning of the work of outstanding personalities that is a new word in the development of modern elitology as the science of elite (as a form) and elitism (as content). The results of the present work concern justification of the need for elite education in the implementation of meritocratic projects and gradual abandoning of the dominance of oligarchic interference in its technological processes. The novelty of this situation lies in the fact that universities have to strengthen their qualitative potential in a transition period from late industrialism to early post-industrialism, which makes its impact on the whole process.
\end{abstract}

Keywords: education, elite, university, meritocracy, professionalism.

\section{Introduction}

The prestige of any university is determined by the quality of educational technologies, the level of professional competence of graduates, and the academic performance of its scientific elite. In the context of the developing information society (digitalization and globalization), the role of such elite educational technologies is increasing and becoming crucial. In this regard, it is the university that provides the main mechanism in the selection of professional

\footnotetext{
* Corresponding author: pavel karabushenko@mail.ru
} 
elites (political, scientific, cultural, etc.), setting them the latest parameters of their competence and instilling in them a sense of responsibility for their activities.

The preliminary hypothesis can be formulated as the assumption that at present, the university is beginning to play an increasingly important role in the process of professional development of elite groups and organizes their searching for responds to contemporary challenges. In this regard, the object of this study is the very elite education, while the subject is the competences of professional elites. The purpose of this work is to reveal the role of elite (open and high-quality) education in the formation of professional qualities of contemporary elites. The authors set the task of clarifying how elite (high-quality) education affects the quality of life of contemporary society. Elite education primarily affects the training of specialists.

In the present research, the authors rely on the principles of classical theories of elites [1], which point to the importance of purposeful formation of elite quality in the subjects of the managerial corps, as well as the research of Russian elitologists [2-4] analyzing the modern features of the selection of professional elite communities. At that, data from the personalist philosophy $[5,6]$ which allow looking into the world of the individual belonging to elite communities are of particular interest in assessing the quality of elite professional communities. Besides, the authors also adhere to the concept of post-industrialism, within which the theory of meritocracy emerged and formed as the elite of the future [7-9]. The article uses an analysis of scientific sources and journalism, as well as memoir literature written by prominent political figures and representatives of the scientific community.

\section{Methods}

In the research, the authors used a methodological complex, applying the methods of dialectics, hermeneutics, comparative studies, and semiotics; used the principles of historicism, objectivism, as well as an integrated approach. Such a methodological set allows not only carrying out the necessary expertise of scientific works on this problem but also making a proper assessment of the current state of elite communities. The authors consider and evaluate the development of new elite professional (meritocratic) communities as a result of their entire historical development.

\section{Elite educational technologies and the challenges of modernity}

There is an opinion that the era of the "revolt of the masses" [10], under whose banner the entire $20^{\text {th }}$ century has passed, has been replaced by the time of the "revolt of the elites" [11], with which the destinies of the $21^{\text {st }}$ century will be associated. The paradox of the current moment is that against the background of the growing influence of elites, their professionalism is notably decreasing (this is especially noted in political professional communities).

Elites are recognized in their professional activities, and the more creative they are, the higher is their professional competence and elitist assessment of their activities. In the production of professional elites, the dominant role is assigned to the university, which is a symbol of the order and universality of human knowledge [12, p. 29]. University implies a knowledge universum. And first of all, the very personality becomes universal.

Certain difficulties are caused by the factor of financial dependence of elite education on various oligarchic structures (grant givers and foundations). To maintain their dominance, oligarchs need to control structures, such as universities, which need financial support to carry out their research activities. But the support by the oligarchs leads to bondage, which 
subordinates science to market laws and the pursuit of profit. As a result, science is increasingly beginning to resemble advertising imitation and blatant scholasticism.

While elitist education is education for the elite (a closed system for the privileged strata of society), then elite education is open and is distinguished by its superiority in educational technologies. The first type of prestigious education is dominated by oligarchic principles of education, while the second type is dominated by meritocratic institutions [13]. While elitist education is aimed at reproducing the elite from the elite, then the elite education develops professional communities, of which the scientific community becomes the main one. This article focuses on meritocratic (elite) education. A comparative analysis of these two systems indicates the dominance of the former in solving contemporary tactical problems and the superiority of the latter in solving strategic problems of the future.

\section{An apology for elite education}

Plato also noted that a professional was someone who surpassed everyone in quality because he was the best at his business [The Republic, 422c-423d]. The subject of the elite was understood by Plato as the dignity of a person elevated from a good to a better state, giving him advantages and certain privileges (statute). Here, the quality of the education received, plays an extremely important role: "proper education and training awaken good natural inclinations in a person, while those who already acquired them become even better due to such education" [The Republic, 424a]. It was for this purpose that Plato implemented the "Academy" project, creating a classic version of the elite scientific and educational system. It was his academy that worked not on the principles of oligarchic superiority (which the sophists specialized in), but on the principles of developing the meritocratic dignity of the individual. Therefore, Plato can be rightly considered the founder of the concept of elite (open) education [14]. J. Lacroix considered that Plato had demonstrated to all the dialectical asceticism of the mind, aimed at improving the soul [5]. Based on this goal-setting, the authors model the foundations of elite education as a system of values aimed at the comprehensive development of the individual. At the time, many researchers wrote about "human capital" linking it with the knowledge economy and smart technologies.

Elite (open to all social strata) quality education is designed to limit the oligarchic principles of elite selection and to establish the only true principle - the principle of meritocracy. The main justification for elite education is the creation of scientific and cultural elites based on the principles of open professional competition. Elite education is aimed at developing the professional competence of a self-sufficient person being able to solve professional problems independently. But its main goal is selecting the scientific elite, designed to form a response to the challenge of its time. As noted by A. Toynbee, the task of the creative minority is to preserve and multiply the creative potential of humanity [15]. If the scientific and cultural elites stop doing this, the world will enter a period of decline and downswing.

\section{Criticism}

According to the authors' analysis, today's pro-elite professional communities obviously lack the level of creativity. Several researchers directly point out that contemporary subjects of political elites chronically lack the depth and quality of professional education and corporate culture $[16,17]$. This is primarily due to a lack of qualitative knowledge. For example, political elites have fallen into the trap of time - they have found themselves in a situation of acute conflict of values of the transition period (from late industrialism to early postindustrialism), where old technologies no longer work, while new ones have not yet replaced 
them. It is the gap in technology that leads to their disorientation and inclination to the values and norms of carnival political culture.

Compensating for the professional shortage, subjects begin to move away from the norms of objective reality toward some artificial forms, in particular, carnival culture. A political carnival is understood as an uncontrolled coven of exalted political actors trying to create a certain parallel reality in which they could assert their superiority and dominance. Carnival brings confusion to the established symbols of the elites, mixing up all their communication links and destroying the classic professional meanings. Instead of scientific data, they begin to use parascientific technologies. At that, the researchers note that the scientific ideas of political leaders do not always correspond to true scientific data. Often, they contradict so much that they cause tangible harm to the entire public consciousness, on which they have direct impact [18].

Research shows that political and scientific elites continue to be heavily dependent on oligarchic and government agencies, which often dictate their terms [19, 20]. Moreover, this fact is very willingly admitted by the politicians themselves, not at all embarrassed by this [21-24]. The meritocracy itself serves as an advertising sign, covering the flaws of the oligarchic principles of elite selection [25, p. 22].

\section{Discussion}

In previous years, studies on the history of universities were regularly published in Europe, which represented a systematic analysis of higher education, scientific knowledge, and the scientific elite [26-29]. Such studies provide the necessary data on the problem under study, especially concerning the history of the development of meritocracy. It can be stated confidently that where the topic of meritocracy is discussed, the problems of elitology education inevitably arise [25]. The conclusions of the authors are partly based on these studies, which reveal the background of the issue under consideration.

The topic discussed in this work has found a very broad discussion in the framework of elitology congresses $(2013,2016,2017,2019)$, which were regularly held by the Russian Elite Community [30-33]. The totality of all these works indicates that the community of Russian elitologists, who were very keenly interested in this problem, paid considerable attention to its analysis. Based on these analyses, one can conclude that meritocracy is gradually becoming one of the most pressing scientific problems. A special analysis of the scientific elite and higher elite education was performed in the research project "Elitology of Education", conducted in Russia in 2017-2020, which resulted in a trilogy of monographs under the same title $[12,13,34]$.

\section{Conclusion}

In recent years, assessing the quality of elite groups has shown an increase in the priority of their professional competence and the level of responsibility for self-made decisions. At that, most researchers point to the university as the cradle of the formation of professional elites. However, in the development of the foundations of elite education, two main problems can be identified. Overcoming these problems will open up new prospects: 1) the existing financial dependence on oligarchic structures, and 2) the possibility of overcoming the historical barrier associated with the transition from a late industrial society to a postindustrial (information) one. 


\section{References}

1. R.A. Nye, The Anti-Democratic Sources of Elite Theory: Pareto, Mosca, Michels, (Sage, Thousand Oaks, 1977)

2. G.K. Ashin, Elitologiya: istoriya, teoriya, sovremennost [Elitology: history, theory, modernity] (MGIMO University, Moscow, 2010)

3. G.K. Ashin, A.V. Ponedelkov, A.M. Starostin, Osnovy politicheskoy elitologii [Fundamentals of political elitology] (Donizdat, Rostov-on-Don, 2012)

4. R.G. Rezakov, Formirovaniye intellektual'noy elity v sisteme nepreryvnogo obrazovaniya [Formation of intellectual elite in the system of lifelong education] (Izdatel'stvo Prometey, Moscow, 2001)

5. J. Lacroix, Le sens du dialogue [The meaning of dialogue] (La Baconnière, Neuchâtel, 1965)

6. N.A. Berdyayev, Smysl tvorchestva [The meaning of creativity], in Filosofiya tvorchestva, kultury, iskusstva, 1, 37-341 (Iskusstvo, Moscow, 1994)

7. D. Bell, The coming of post-industrial society: a venture in social forecasting (Basic Books , New-York, 1976)

8. M. Young, The Rise of the Meritocracy: 1870 - 2033: An Essay on Education and Equality (Thames and Hudson, London, 1958)

9. A. Toffler, Future shock (Random House, Curtis Brown, Ltd., New York, 1970)

10. J. Ortega y Gasset, The revolt of the Masses (W.W. Norton Company, New York, 1994)

11. Ch. Lasch, The revol of the elits and the betrayal of democracy (W.W. Norton Company, New York, 1996)

12. P.L. Karabushchenko, L.Ya. Podvoysky, R.G. Rezakov, Elitologiya obrazovaniya: elita i universitet [Elitology of Education: Elite and University] (Econ-Inform, Moscow, 2019)

13. P.L. Karabushchenko, R.G. Rezakov, L.Ya. Podvoysky, Elitologiya obrazovaniya: osnovy pedagogicheskoy selektsii elit [Elitology of education: the basics of pedagogical selection of elites] (Econ-Inform, Moscow, 2018)

14. L.Ya. Podvoysky, Platonosfera [Platonosphere] (Econ-Inform, Moscow, 2020)

15. A.J. Toynbee, S.F. Huntington, Vyzovy i otvety. Kak gibnut tsivilizatsii [Challenge and response. The death of civilizations] (Algorithm, Moscow, 2016)

16. V. Trierweiler, Merci pour ce moment [Thank You for This Moment] (Les Arènes, Paris, 2014)

17. M. Wolff, Fire and Fury: Inside the Trump White House (Henry Holt and Co., New York, 2018)

18. R.U. Woodward, Rage (Simon \& Schuster, New York, 2020, 480)

19. U. Ulfkotte, Gekaufte Journalisten: Wie Politiker, Geheimdienste und Hochfinanz Deutschlands Massenmedien lenken. Auflage 5 (Kopp Verlag, 2014)

20. P.C. Roberts, How America was Lost. From 9/11 to the Police/Warfare State (Clarity Press, Atlanta, 2014)

21. J.D. Trump, Crippled America: How to Make America Great Again (Threshold Editions, New York, 2015)

22. E. Macron, Révolution (XO Éditions, Paris, 2016)

23. H.R. Clinton, What Happened (Simon \& Schuster, New York, 2017) 
24. F. Hollande, Un président travaille toujours pour son succésseur [A president always works for his successor], L'Obs Paris, 2788, 20-25 (2018)

25. Ch. Hayes, Twilight of the Elites: America after Meritocracy (Crown Publishing Group, New York, 2012)

26. W. Rudy, The Universities of Europe, 1100-1914: a history (Prentice Hall, Englewood cliffs, New Jersey, 1987)

27. H. de Ridder-Symoens (Ed.), A History of the University in Europe, vol. I Universities in the Middle Ages (Cambridge University Press, Cambridge, 1992)

28. W. Rüegg, Una Historia da Universidade na Europa, Vol. II As Universidades na Europa Moderna (Imprensa Nacional-Casa da Moeda, Lisboa, 2002)

29. W. Rüegg, Geschichte der Universität in Europa, Band IV: Vom Zweiten Weltkrieg bis zum Ende des zwanzigsten Jahrhunderts (C.H. Beck Verlag, München, 2010)

30. V.V. Rudoy (Ed.), Elitologiya Rossii: sovremennoye sostoyaniye i perspektivy razvitiya [Elitology of Russia: current state and development prospects]. Proceedings of the first all-Russian elitological congress with international participation, 7-8 October 2013, Rostov-on-Don, Russia (Publishing house of the South-Russian Institute of Management - branch of RANEPA, Rostov-on-Don, 2013)

31. Yu. Shutov, O.V. Lokota (Eds.), Elitologiya i strategii razvitiya sovremennoy Rossii [Elitology and development strategies of modern Russia]. Proceedings of the second all-Russian elitological congress with international participation, 21-22 October 2016, Rostov-on-Don, Russia, 1 (Publishing house of the South-Russian Institute of Management - branch of RANEPA, Rostov-on-Don, 2016)

32. A.P. Lunev, P.L. Karabushchenko (Eds.), Elity i lidery: strategii formirovaniya $v$ sovremennom universitete [Elites and Leaders: Formation Strategies in a Modern University]. Proceedings of the International congress, 19-22 April 2017, Astrakhan, Russia (Astrakhan University Publishing House, Astrakhan, 2017)

33. A.V. Ponedelkov (Ed.), Rossiyskaya elitologiya: innovatsionnyye otvety na vyzovy sovremennogo mira [Russian elitology: innovative responses to the challenges of the modern world]. Proceedings of the Third all-Russian elitological congress with international participation, 15-16 February 2019, Rostov-on-Don, Russia (Publishing house of the South-Russian Institute of Management - branch of RANEPA, Rostov-onDon, 2019)

34. P.L. Karabushchenko, R.G. Rezakov, L.Ya. Podvoysky, Elitologiya obrazovaniya: genezis nauchnoy elity [Elitology of education: genesis of the scientific elite] (EconInform, Moscow, 2020) 